\title{
Effect of supportive periodontal treatment in the oral lichen planus patients
}

\author{
Eun-Young Kwon*, Jeomil Choi, Ju-Youn Lee \\ Department of Periodontology, School of Dentistry, Pusan National University, Yangsan, Republic of Korea
}

Lichen planus is an immune-mediated mucocutaneous disease, affects more frequently middle-aged Caucasian women and makes signs and symptoms in the oral mucosa. Cutaneous lichen planus lesions cause itching but they are self-limiting, oral lichen planus lesions are usually chronic, recalcitrant to treatment and potentially premalignant in some cases. Although, oral lichen planus is non-plaque related disease, they possess particular problems because plaque control is complicated by pain and bleeding and might cause plaque-related disease. The resulting condition comprises accumulations of plaque, which again can influence the progress of oral lichen planus with burning sensation, spontaneous gingival bleeding. Thus, it should be noted that both medication and supportive periodontal treatment are essential for the remission of the lesions. This case report introduces topical corticosteroid therapy and supportive periodontal treatment including intensive oral hygiene procedures to obtain an improvement of subjective symptoms and objective changes and to prevent relapse the lesions. (J Dent Rehabil Appl Sci 2015;31(2):134-42)

Key words: lichen planus; periodontal diseases; oral hygiene

\section{서론}

점막피부 질환에는 편평태선, 점막 유천포창, 심상성 천포창 등이 있으며, 이 중 편평태선은 면역 매개 점막피 부 질환으로 병인은 여전히 알려져 있지 않다. ${ }^{1}$ 편평태선 은 중년의 백인 여성에서 흔히 발생하고 구강 점막에서 증상이나 징후가 생기기도 한다. ${ }^{2}$ 편평태선의 피부 병소 는 가려움을 유발하나 자기 제한적이고, 구강편평태선의 구강 병소는 만성적이고 좀처럼 스스로 치유되지 못하고, 드물긴 하나 잠재적으로 전암 병소로 발전할 수 있다. ${ }^{3}$

구강편평태선은 편평태선과는 다르게 치료에 잘 반응 하지 않으며, ${ }^{4}$ 유병률은 대략 $1.27 \%$ 정도로 보고되고 30 - 60세 여성에서 호발한다. ${ }^{5}$ 치은은 협점막, 혀 이외에 구 강편평태선이 가장 잘 호발하는 지역 중 하나이며, 치은

*Correspondence to: Eun-Young Kwon

Clinical Assistant Professor, Department of Periodontology, School of Dentistry, Pusan National University, Pusan National University Hospital, Gudeok-ro 305, Seo-gu, Busan, 602-739, Republic of Korea

Tel: +82-51-240-7429, Fax: +82-51-240-7706, E-mail: betteryoung@hanmail.net Received: April 2, 2015/Last Revision: April 28, 2015/Accepted: May 31, 2015
에만 한정된 경우는 $8.6 \%$ 에서 $10 \%$ 정도로 보고된다. ${ }^{6}$ 구 강편평태선을 지닌 환자는 하나 또는 그 이상의 구강 외 부에서 동시적인 질환을 가지고 있는 경우가 있으며, $15 \%$ 정도에서 피부 질환이 발생한다고 한다. 따라서, 구 강 외부에서 침범한 잠재적 부위를 찾기 위해 철저한 검 사와 다분야간 협진이 필요하다. ${ }^{3}$

구강편평태선의 가장 흔한 형태는 망상형(reticular)이 며, 미란형(erosive)/궤양형(ulcerative), 위축형(atrophic)/ 홍반형(erythematous)이 뒤를 따른다. 망상형은 고립된 병 소로 나타나고, 홍반형은 망상형과 동반되고, 미란형은 거 의 모든 증례에서 망상형, 홍반형과 동반된다. 이것은 구 강편평태선이 홍반, 미란의 고립된 부위로 특징지어지는 천포창, 유천포창 등의 다른 수포성-미란형 질환(vesiculoerosive diseases)과 임상적으로 구분되게 해 준다. ${ }^{3}$

Copyright $@ 2015$ The Korean Academy of Stomatognathic Function and Occlusion. (c) It is identical to Creative Commons Non-Commercial License. 
망상형은 백색 병소를 대표하며, 이것은 백색 선을 연 결하여 엮은 네트워크로 보인다. 비록 몇몇 환자들은 방 산형으로 넓게 퍼진 망상형 병소의 인상적인 배열을 가 지고 있으나, 대개는 증상을 호소하는 경우가 거의 없 고, 종종 존재 자체를 인지하지 못하는 경우도 있다. 그 러나 미란형은 좀처럼 저절로 낫지 않고, 다른 자가면 역 점막, 수포성-미란형 질환과 종종 혼동을 야기한다. 미란형, 홍반형 병소는 다양한 정도의 통증을 야기하는 데, 미란형 구강편평태선에서는 가끔 쉽게 터지는 수포 (bulla)가 관찰되기도 하며, 궤양이 치은에 국한된 경우 박리성 치은염이 발생하기도 한다. 박리성 치은염은 상 피 탈락(epithelial desquamation), 위축, 궤양, 수포성 병 소를 지닌 홍반으로 임상적으로 특징지어지며, 전치부 와 구치부에서 변연치은과 부착치은 둘 다에서 나타날 수 있다. ${ }^{5}$

구강편평태선을 악화시키는 소인으로는 스트레스, 치 과 치료로 인한 기계적 외상, 흡연, 바이러스, 불량한 구 강 위생 등이 있다. ${ }^{7,8}$ 구강편평태선을 지닌 환자들은 더 높은 수준의 불안과 우울 그리고 정신 질환에 더욱 취 약한 특징을 지닌 경우가 많다. 치과 치료로 인해 기계 적 외상을 입거나 구강 내 거친 수복물, 잘 맞지 않는 보 철물, 날카로운 교두로부터 마찰, 흡연으로 인한 열 등 은 악화 요소가 될 수 있다. 또한 구강편평태선의 발병 에서 중요한 역할을 하는 바이러스는 헤르페스 바이러 스(herpes virus), 엡스타인바 바이러스(Epstein-Barr virus), 인유두종 바이러스(human papilloma virus), C 형 간염 바이러스(hepatitis C virus) 등이 있다. ${ }^{9}$ 특히 구 강편평태선 환자의 혈청에서 $\mathrm{C}$ 형 간염 바이러스의 염기
서열이 발견되었다는 보고는 C형 간염 바이러스가 구강 편평태선 환자의 점막 손상의 발생에 기여할 수 있다는 것을 뒷받침 해준다. ${ }^{3}$

구강편평태선은 비록 비치태 연관 질환(non-plaquerelated diseases)이나 통증, 출혈로 인해 적절한 치 태 조절이 어렵게 되어 치태 연관 질환(plaque-related diseases)을 야기할 수 있고, 작열감, 자발적인 출혈 등 구강편평태선과 관련된 점막 증상이 축적된 치태에 의 해 더욱 악화될 수 있다. ${ }^{10}$ 따라서 구강편평태선 환자에 서 구강편평태선 자체의 약물적 치료뿐만 아니라 적절 한 구강 위생 관리, 치석 제거 등의 치주치료가 동반되 어야 한다. 본 연구에서는 구강편평태선 환자에서 치주 치료를 동반하여 증상 및 징후가 개선된 증례를 보고하 고자 한다.

\section{증례 보고}

\section{1. 증례 1}

47세의 여자 환자가 잇몸이 따가워서 양치질하기 힘 들다는 주소로 치주과에 내원하였다. 환자의 구내 검사 시 치은에서 미란과 홍반이 관찰되었고, 통증과 출혈 때 문에 양치질에 의한 치태 조절이 거의 불가능한 상태였 다(Fig. 1). 병소는 구강내 치은에서만 관찰되었고, 피 부 병소는 관찰되지 않았다. $4 \mathrm{~mm}$ 를 초과하는 깊은 치 주낭이나 동요도를 보이는 치아는 없었고, 방사선 사진 상 하악 좌측 제1대구치(\#36) 이개부 치조골 소실이 국 소적으로 보였으나, 수직적 골소실을 보이는 곳은 없었

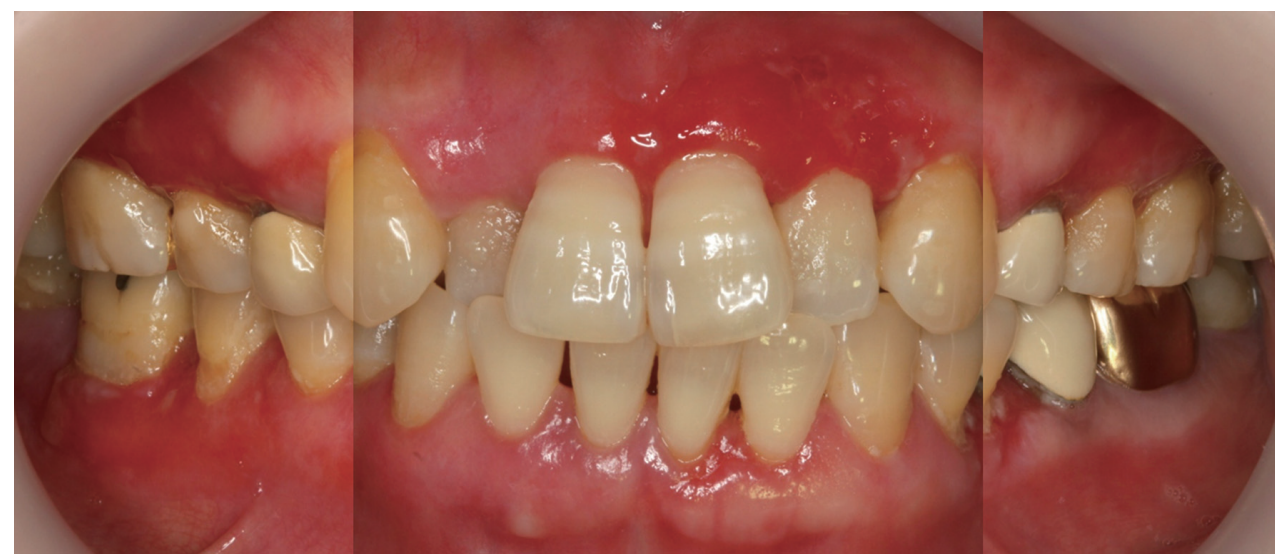

Fig. 1. Pretreatment clinical view of case 1. Note the gingival erosion and erythema and accumulation of dental plaque. 
다(Fig. 2). 진단은 경도의 만성 치주염 및 구강편평태 선으로 내리고, 원활한 치태조절을 위해 먼저 구강편 평태선 통증 완화 치료를 시행하기로 계획하였다. 국 소적인 코르티코스테로이드를 사용하기로 했으며 구 내 국소도포는 점막에 오랫동안 부착된 경우에만 효과 가 있으므로 구강세척액으로 덱사메타손 구강세척액 (dexamethasone gargle 0.05\%)을 하루 4번 사용하도록 지시하였고 저자극성 치약과 부드러운 칫솔을 사용하 여 양치질 하도록 구강위생교육을 하였다. 약 3 주 후 양
치질시 통증이 많이 완화되어서 초진시보다 치태조절이 원활히 되는 것을 확인하였으며, 전악 치석제거, 치근활 택술을 시행하였다(Fig. 3). 이후 매달 내원시켜 전문가 치태조절을 시행하였으며, 6 개월이 지난 후 구강편평태 선 병소는 거의 사라진 것을 확인 후 지속적인 정기 점 검을 실시하고 있다(Fig. 4). 치료 시작 후 2 년이 되는 시 점까지 구강편평태선이 재발하지 않고 환자의 구강위생 도 잘 조절되고 있음을 확인하였다(Fig. 5).

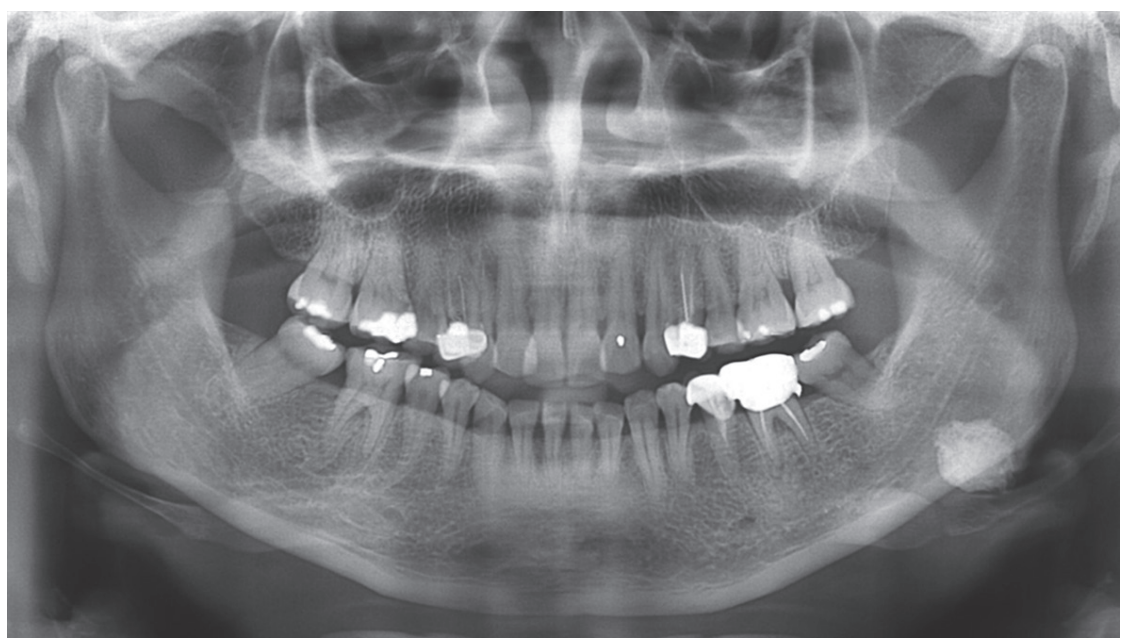

Fig. 2. Pretreatment radiograph of case 1. Although furcation involvement of left lower first molar region was found, generalized alveolar bone loss was not severe.

\section{Treatment goal: Relief of symptoms and} remission of lesions

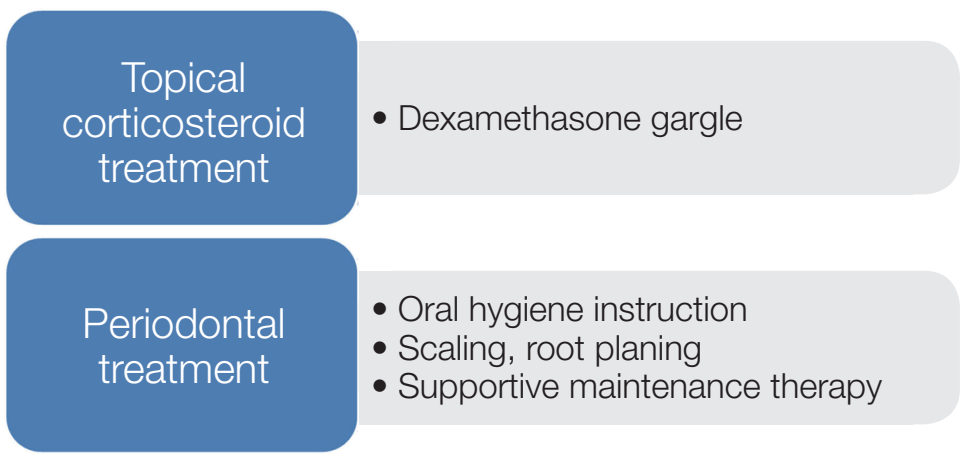

Fig. 3. A diagram representing combined treatment approach. 


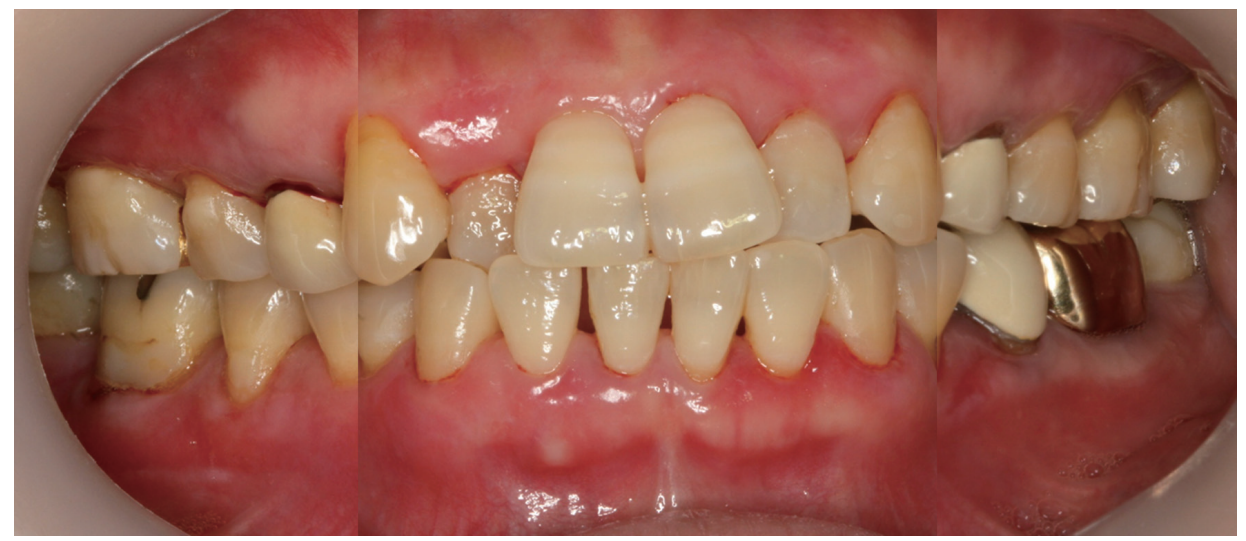

Fig. 4. Posttreatment at 6 month of case 1. Note the remission of gingival erosion and erythema and improvement of oral hygiene.

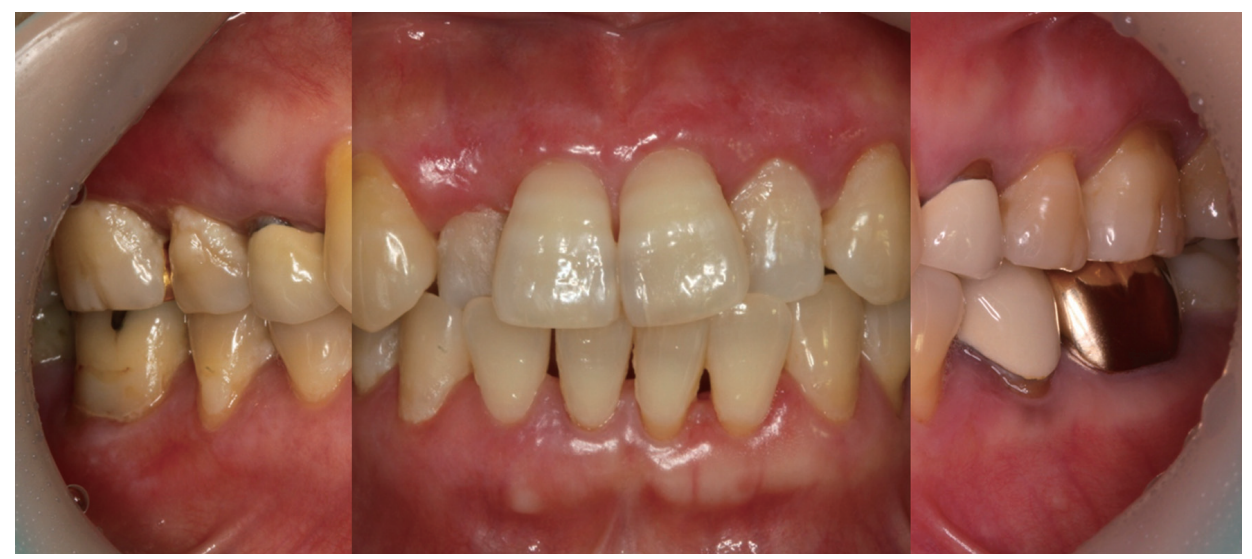

Fig. 5. Posttreatment at 2 year of case 1 . Note no relapse of oral lichen planus and maintenance of gingival health.

\section{2. 증례 2}

56세의 여자 환자로 구강편평태선으로 구강내과에서 지속적인 치료를 받고 있으나, 계속되는 치은 통증과 치 은 부종으로 치주과로 의뢰되었다. 구내 검사시 치은의 미란과 홍반이 관찰되었고, 하악 좌측 제2대구치(\#37) 와 하악 우측 제1대구치(\#46) 부위에서 치은 부종과 농 양, 탐침시 출혈이 관찰되었고 특히 하악 좌측 제 2 대구 치에서 수직적 골소실과 함께 2도의 동요도, $7-8 \mathrm{~mm}$ 정도의 치주낭이 존재하였다(Fig. 6, 7). 상악 우측 대구 치를 치주염으로 3 년전 상실한 이후 구강편평태선으 로 보철 치료를 받지 못하여 좌측만 저작을 하여 국소적
인 치주염이 악화된 것으로 추측되었다. 또한 구강편평 태선으로 적극적인 치태관리를 환자 스스로 하지 못해 구강내 전반적인 중등도의 만성 치주염이 악화되었다 고 진단내리고, 덱사메타손 구강세척액(dexamethasone gargle $0.05 \%$ ) 등의 국소적인 코르티코스테로이드 치료 에 덧붙여 적극적인 치주치료를 시행하기로 하였다. 전 악에 걸친 치석제거, 치주소파술을 시행한 후 하악 대구 치 부위에는 추가적으로 바스법의 양치질 교육을 시키 고 3개월마다 정기 점검을 실시하였다(Fig. 3). 치료 시 작 후 1 년이 되는 시점까지 구강편평태선이 악화되지 않고 하악 대구치 부위의 치은 통증, 부종 등도 많이 완 화된 소견이 관찰되었다(Fig. 8). 


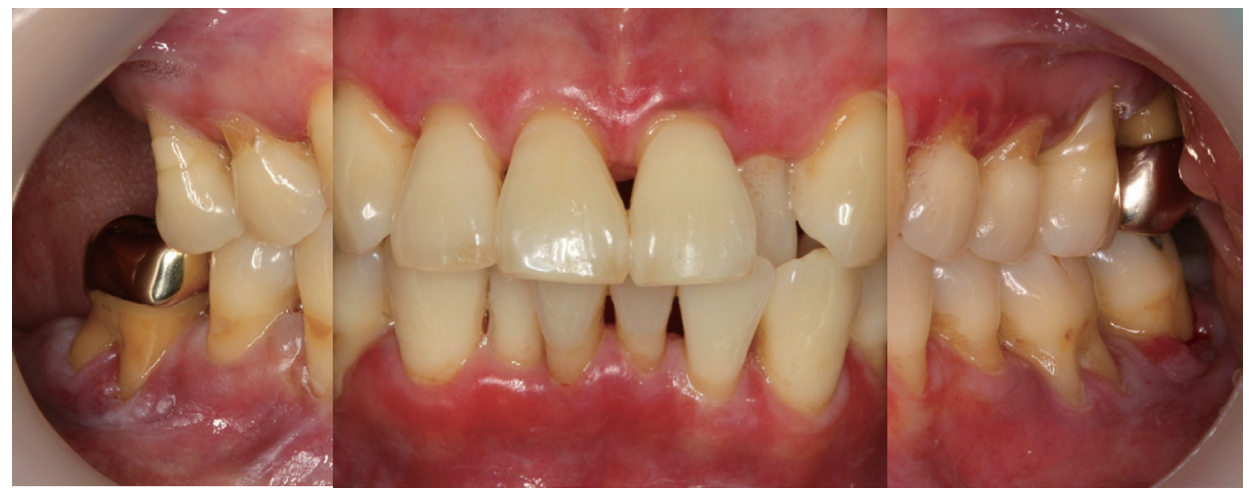

Fig. 6. Pretreatment clinical view of case 2. Note the gingival erosion and erythema with gingival swelling and abscess at lower molar areas.

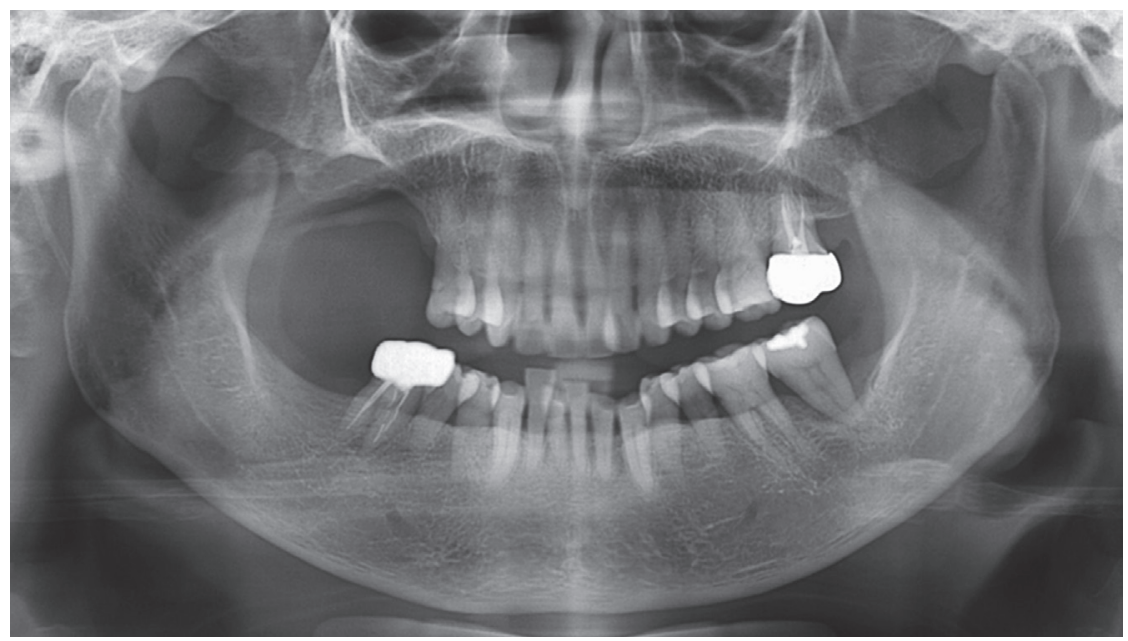

Fig. 7. Pretreatment radiograph of case 2. Although vertical bone defect of left lower second molar region was found, generalized horizontal alveolar bone loss was well maintained.

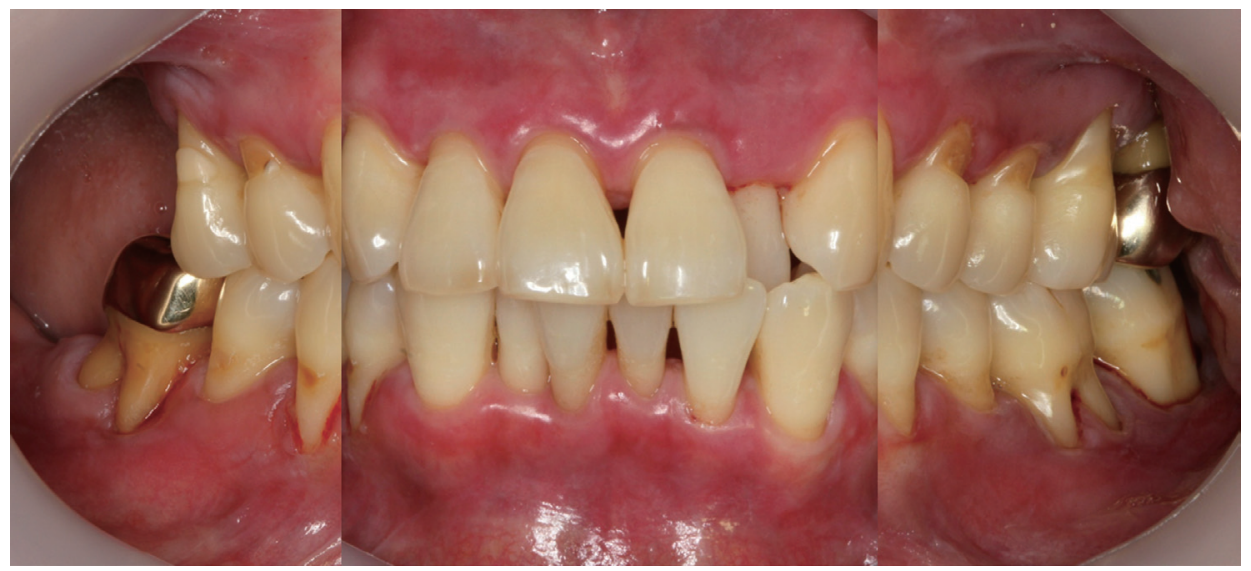

Fig. 8. Posttreatment at 1 year of case 2. Note the remission of gingival erosion and erythema and subsided state of lower molar areas. 


\section{고찰}

구강편평태선의 임상적 특징은 정확한 진단을 내리는 데 있어 어려움을 초래할 수 있다. 그러나 조직병리적 평가와 함께 절개생검은 임상적 진단을 내리고, 이형성, 악성 가능성을 배제하기 위해 추천된다. ${ }^{5}$ 진단은 구강편 평태선의 임상적, 조직학적 검사에 근거를 두는데, 임상 적 특징은 구강 점막에서 양측성의 레이스와 같은 각화 성 망상형, 구진형(keratotic reticular, popular) 병소 뿐 만 아니라, 미란형/궤양형, 위축형 병소 등을 대표적으 로 꼽을 수 있다. ${ }^{11}$ 조직학적 특징은 과각화증, 기저세포 의 퇴행성 변화, 림프구와 조직구로 구성된 밴드 모양의 상피하 염증성 침윤이다. ${ }^{12}$ 본 증례에서는 절개생검은 하지 못하고, 임상적 특징에 근거하여 구강편평태선으 로 진단을 내리고 치료하였으나 절개생검을 통한 조직 학적 평가를 동반했다면 확진에 더욱 도움이 되었을 것 이다.

구강편평태선이 위축형 또는 궤양형 병소일 때, 통증 과 출혈로 양치질이 어렵기 때문에 치태, 치석 축적이 야기되어 위축형-미란형 치은 병소의 발생률을 더 높이 게 되는 등 구강편평태선의 진행에 다시 영향을 주게 된 다. ${ }^{13}$ 또한, 이러한 구강편평태선은 적절한 구강 위생 조 절을 방해하여 치태에 의해 유도된 치주 질환의 장기간 의 위험도를 간접적으로 증가시키게 된다. ${ }^{10}$

구강편평태선 환자에서 치주 질환의 심도는 악화 된 구강편평태선 병소의 증상과 더불어 깊어지고, 이 로 인해, 치주 질환을 야기하는 미생물(Aggregatibacter actinomycetemcomitans, Porphyromonas gingivalis, Prevotella intermedia, Tannerella forsythia, Treponema denticola)의 양을 증가시킨다. 바이러스와 유사하게 치주 질환을 야기하 는 미생물은 구강편평태선의 발병에서 중요한 역할을 한다. 구강편평태선과 치주 질환을 야기하는 미생물간 관계는 2 가지 가설에 의해 설명될 수 있다.

첫 번째는 구강편평태선 병소의 형성 이후 치주 질환 을 야기하는 미생물의 수의 증가이다. 치태, 치석과 같 은 국소적 요인들은 구강편평태선 병소의 치유를 억제 하여 구강편평태선을 더욱 공격적인 형태로 전환시킨 다. 이로 인해 구강 위생 관리는 더욱 어려워지며, 치주 염의 심도가 깊어지고 치주 질환을 야기하는 미생물의 수가 증가할 수 있다. 두 번째는 치주 질환을 야기하는 미생물이 구강편평태선의 발생에서 직접적인 역할을 하 여 구강편평태선 병소의 형성을 야기할 수 있다는 것이
다. 다만, 구강편평태선과 치주 질환을 야기하는 미생물 간의 관계를 이해하기 위해 장기간의 임상 연구가 이루 어져야 할 것이다. ${ }^{9}$

구강편평태선 치료는 위축형, 궤양형 병소를 제거하 고, 증상을 경감시키는데 목표를 둔다. 무증상인 망상 형 병소는 일반적으로 치료를 필요로 하지 않으나, 병소 자체의 변화에 대한 관찰은 필요로 한다. 만일 날카로 운 수복물 변연이나 불량하게 적합된 의치와 같은 기계 적 손상 등이 원인이라면, 이를 먼저 해결해야 할 것이 다. 또한 유태선 약물반응(lichenoid reaction) 등이 존재 한다면 약물을 중단하는 것만으로도 치료가 가능하므로 이전에 사용한 약물에 대해 자세히 조사해야 한다. ${ }^{3}$

다양한 치료 방법들이 병소 상태를 향상시키고 관련 된 통증을 감소시키기 위해 제안되어 왔으나 구강편평 태선에 대한 정확한 치료 프로토콜이 아직 확립되지 못 했다. 구강편평태선을 치료하기 위해 많은 약물이 사용 되었으며 그 중 가장 효과적이고 부작용이 적은 것으로 알려진 것은 국소적인 코르티코스테로이드 치료이며, 여기에는 betamethasone, clobetasol, dexamethasone, triamcinolone 등이 있다. ${ }^{14}$ 국소적인 코르티코스테로 이드 치료는 구강편평태선 치료에서 가장 널리 쓰이 지만, 구강 내 병소에 대하여 부착 부족으로 장시간 효 과를 지속적으로 내기 어렵고, 광범위한 병소에는 전 체적으로 적용하기 어렵다는 단점이 있다. ${ }^{1}$ 따라서 dexamethasone, triamcinolone, clobetasol과 같은 구강 세척액 형태의 국소적인 코르티코스테로이드가 광범위 한 구강 병소를 지니고 있거나 구강 내 기술적으로 도포 하기 힘들어하는 고령의 환자에서 사용이 추천된다. 또 한 국소적인 코르티코스테로이드 치료로는 잘 낫지 않 는 미란형 또는 홍반형의 구강편평태선을 가지고 있는 경우 또는 피부, 생식기, 식도, 두피 등을 침범한 구강편 평태선을 가지고 있는 경우에는 전신적인 코르티코스테 로이드 복용이나 cyclosporine, tacrolimus, pimecrolimus 또는 tretinoin 등과 같은 면역억제제 복용이 고려되어야

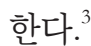

코르티코스테로이드의 장기간의 사용은 감소된 생물 학적 효과(biological effectiveness)를 야기하는데, 이는 약제를 하루씩 걸러 사용하거나 초기에 매우 강력한 코 르티코스테로이드(예, clobetasol)를 사용하고, 이후 중 등도의 코르티코스테로이드(예, triamcinolone)를 사용 하여 피할 수 있다. 또한, 미란이 치유되고 홍반형 병소 가 무증상이 되자마자 강도가 낮은 약물로 교체하거나, 
치료를 일시적으로 중단하는 것이 추천되기도 한다. 구 강편평태선 환자의 $1 / 3$ 정도에서 이차성 칸디다증이 발 생하기도 하는데, 이럴 경우 항진균 치료를 필요로 하기 도 한다. ${ }^{15}$ 그러나 코르티코스테로이드 치료는 치료를 중단하면 재발이 흔하고 다양한 임상적 형태의 병소에 서 장기간의 치료에는 효과가 떨어지기 때문에 결국은 보다 근본적으로 금연, 기계적 손상 등의 국소적 요소가 제거되었는지 주의를 기울이고, 효과적인 치태조절을 수행할 수 있도록 교육 해야만 한다. ${ }^{11}$ 많은 연구들에서 치태조절에 초점을 맞춘 치주 치료와 함께 국소적인 코 르티코스테로이드 치료를 한 경우 좋은 결과를 보였고, 이것은 구강편평태선 증상 해소에도 더욱 좋은 결과를 보였다. ${ }^{2}$

따라서 구강편평태선 환자에서 치은 건강을 유지하기 위한 핵심 요소는 국소적인 코르티코스테로이드 치료 사용 이외에도 적절한 구강 위생 조절 수단을 통해 치 태, 치석 관리를 지속적으로 하는 것이다. ${ }^{1}$ 치태 조절은 구강편평태선의 근본적인 원인을 제거하지는 않지만, 적절한 구강 위생 관리를 통해 구강편평태선에서 주관 적인 증상의 향상과 객관적인 징후의 변화를 이끌 수 있 다. 이를 위해 비외상성의 구강 위생 관리, 클로르헥시 딘 구강세척액(chlorhexidine mouth washes) 사용 등이 제시되어 왔다. ${ }^{12}$ 다른 연구에서는 국소적인 코르티코스 테로이드 치료와 함께 치은연상, 치은연하 치석제거가 동반되기도 하였다. ${ }^{1,10}$

본 증례에서도 환자들은 초진시 구강편평태선으로 인 해 양치질시 극심한 통증과 출혈로 구강 위생 관리를 전 혀 하지 못하는 상태였고, 이로 인해 치은 염증 및 증상 이 더욱 악화되고 있었다. 우선 국소적인 코르티코스테 로이드 치료로 증상을 완화시킴과 동시에 저자극성 치 약을 이용하여 집에서 양치질을 효과적으로 할 수 있도 록 교육시키고 치석제거, 치근활택술 또는 치주소파술 을 동반한 치주치료를 진행하였다. 그 결과 환자의 구강 편평태선 병소의 크기나 범위도 많이 감소하였고 치은 출혈, 통증 등의 증상도 현저한 개선을 보였다. 또한 구 강편평태선으로 오랜 기간 국소적인 코르티코스테로이 드 치료를 받고 있음에도 통증 등이 조절되지 않는 경우 에도 추가적인 치주치료로 통증 완화 및 구강편평태선 병소 개선 및 치주염 치료까지 효과를 볼 수 있었다.

\section{결론}

구강편평태선은 중년의 여성에서 종종 나타나는 구강 점막 질환으로 국소적인 코르티코스테로이드 치료뿐만 아니라 구강 위생 교육을 포함한 치주 치료를 통해 증상 및 징후를 개선시키고 재발 방지를 도울 수 있다.

\section{Acknowledgements}

본 연구는 2015년도 부산대학교병원 임상연구비 지원 으로 이루어졌음.

\section{Orcid}

Eun-Young Kwon http://orcid.org/0000-0001-9555-0360

Jeomil Choi http://orcid.org/0000-0002-7491-6711

Ju-Youn Lee http://orcid.org/0000-0002-0772-033X

\section{References}

1. Guiglia R, Di Liberto C, Pizzo G, Picone L, Lo Muzio L, Gallo PD, Campisi G, D'Angelo M. A combined treatment regimen for desquamative gingivitis in patients with oral lichen planus. J Oral Pathol Med 2007;36:110-6.

2. Salgado DS, Jeremias F, Capela MV, Onofre MA, Massucato EM, Orrico SR. Plaque control improves the painful symptoms of oral lichen planus gingival lesions. A short-term study. J Oral Pathol Med 2013;42:728-32.

3. Eisen D, Carrozzo M, Bagan Sebastian JV, Thongprasom K. Number $\mathrm{V}$ oral lichen planus: clinical features and management. Oral Dis 2005;11:33849.

4. Choonhakarn C, Busaracome P, Sripanidkulchai B, Sarakarn P. The efficacy of aloe vera gel in the treatment of oral lichen planus: a randomized controlled trial. Br J Dermatol 2008;158:573-7.

5. Lodi G, Carrozzo M, Furness S, Thongprasom K. Interventions for treating oral lichen planus: a systematic review. Br J Dermatol 2012;166:938-47.

6. Scully C, el-Kom M. Lichen planus: review and update on pathogenesis. J Oral Pathol 1985;14:431-58.

7. Eisen D. The clinical features, malignant potential, 
and systemic associations of oral lichen planus: a study of 723 patients. J Am Acad Dermatol 2002; 46:207-14.

8. Gorsky M, Raviv M. Efficacy of etretinate (tigason) in symptomatic oral lichen planus. Oral Surg Oral Med Oral Pathol 1992;73:52-5.

9. Ertugrul AS, Arslan U, Dursun R, Hakki SS. Periodontopathogen profile of healthy and oral lichen planus patients with gingivitis or periodontitis. Int J Oral Sci 2013;5:92-7.

10. López-Jornet P, Camacho-Alonso F. Application of a motivation-behavioral skills protocol in gingival lichen planus: a short-term study. J Periodontol 2010;81:1449-54.

11. Thorn JJ, Holmstrup P, Rindum J, Pindborg JJ. Course of various clinical forms of oral lichen planus. A prospective follow-up study of 611 patients.
J Oral Pathol 1988;17:213-8.

12. Holmstrup P, Schiøtz AW, Westergaard J. Effect of dental plaque control on gingival lichen planus. Oral Surg Oral Med Oral Pathol 1990;69:585-90.

13. Ramón-Fluixá C, Bagán-Sebastian J, MiliánMasanet M, Scully C. Periodontal status in patients with oral lichen planus: a study of 90 cases. Oral Dis 1999;5:303-6.

14. Lo Russo L, Fedele S, Guiglia R, Ciavarella D, Lo Muzio L, Gallo P, Di Liberto C, Campisi G. Diagnostic pathways and clinical significance of desquamative gingivitis. J Periodontol 2008;79:4-24.

15. Vincent SD, Fotos PG, Baker KA, Williams TP. Oral lichen planus: the clinical, historical, and therapeutic features of 100 cases. Oral Surg Oral Med Oral Pathol 1990;70:165-71. 


\section{구강편평태선 환자에서 보조적 치주치료의 효과}

\section{권은영*, 최점일, 이주연}

부산대학교 치의학전문대학원 치주과학교실

편평태선은 면역 매개 점막피부 질환으로 병인은 여전히 알려져 있지 않고, 중년의 백인 여성에서 흔히 발생하고 구강 점막에서 증상이나 징후가 생기기도 한다. 편평태선의 피부 병소는 가려움을 유발하나 자기 제한적이고, 구강편평태선 의 구강 병소는 만성적이고 좀처럼 스스로 치유되지 못하고, 드물긴 하나 잠재적으로 전암 병소로 발전할 수 있다. 구 강편평태선은 비록 비치태 연관 질환이나 통증, 출혈로 인해 적절한 치태 조절이 어렵게 되어 치태 연관 질환을 야기할 수 있고, 작열감, 자발적인 출혈 등 구강편평태선과 관련된 점막 증상이 축적된 치태에 의해 더욱 악화될 수 있다. 따라 서 구강편평태선 환자에서 구강편평태선 자체의 약물적 치료뿐만 아니라 적절한 구강 위생 관리, 치석 제거 등의 치주 치료가 동반되어야 한다. 본 증례에서는 구강편평태선 환자에서 국소적인 코르티코스테로이드 치료뿐만 아니라 구강 위생 교육을 포함한 치주 치료를 통해 증상 및 징후를 개선시키고 재발 방지를 도울 수 있었다.

(구강회복응용과학지 2015;31 (2):134-42)

주요어: 편평태선; 치주질환; 구강 위생

*교신저자: 권은영

(602-787) 부산시 서구 구덕로 305 부산대학교병원 치과진료처 치주과

Tel: 051-240-7429 | Fax: 051-240-7706 | E-mail: betteryoung@hanmail. net

접수일: 2015년 4월 2일 | 수정일: 2015년 4월 28일 | 채택일: 2015년 5월 31일 